University of Vermont

UVM ScholarWorks

$1-1-2014$

\title{
A cosmogenic view of erosion, relief generation, and the age of faulting in southern Africa
}

\author{
Paul R. Bierman \\ University of Vermont \\ Ryan Coppersmith \\ Coppersmith Consulting Inc. \\ Kathryn Hanson \\ AMEC \\ Johann Neveling \\ Council for Geoscience \\ Eric W. Portenga \\ University of Glasgow
}

See next page for additional authors

Follow this and additional works at: https://scholarworks.uvm.edu/casfac

Part of the Climate Commons

\section{Recommended Citation}

Bierman PR, Coppersmith R, Hanson K, Neveling J, Portenga EW, Rood DH. A cosmogenic view of erosion, relief generation, and the age of faulting in southern Africa. GSA Today. 2014 Sep;24(9):4-11.

This Article is brought to you for free and open access by the College of Arts and Sciences at UVM ScholarWorks. It has been accepted for inclusion in College of Arts and Sciences Faculty Publications by an authorized administrator of UVM ScholarWorks. For more information, please contact scholarworks@uvm.edu. 


\section{Authors}

Paul R. Bierman, Ryan Coppersmith, Kathryn Hanson, Johann Neveling, Eric W. Portenga, and Dylan H. Rood 


\section{A cosmogenic view of erosion, relief generation, and the age of faulting in southern Africa}

Paul R. Bierman, Geology Department and Rubenstein School of the Environment and Natural Resources, University of Vermont, Burlington, Vermont 05405, USA, pbierman@uvm.edu; Ryan Coppersmith, Coppersmith Consulting Inc., 2121 N. California Blvd. Suite 290, Walnut Creek, California 94596, USA, ryan@ coppersmithconsulting.com; Kathryn Hanson, AMEC Environment \& Infrastructure, Inc., 180 Grand Avenue, Suite 1100, Oakland, California 94612, USA, kathryn.hanson@amec.com; Johann Neveling, Council for Geoscience, 280 Pretoria Street, Silverton, Pretoria 0184, South Africa, jneveling@geoscience.org.za; Eric W. Portenga, School of Geographical and Earth Sciences, University of Glasgow, Glasgow G12 800, UK, and Department of Environment and Geography, Macquarie University, North Ryde NSW 2109, Australia, e.portenga.1@research.gla.ac.uk; Dylan H. Rood, Scottish Universities Environmental Research Centre (SUERC), University of Glasgow, East Kilbride G75 OOF, Scotland, UK, and Earth Research Institute, University of California, Santa Barbara, California 93106, USA, and Center for Accelerator Mass Spectrometry, Lawrence Livermore National Laboratory, Livermore, California 94550, USA, drood@eri.ucsb.edu

\section{ABSTRACT}

Southernmost Africa, with extensive upland geomorphic surfaces, deep canyons, and numerous faults, has long interested geoscientists. A paucity of dates and low rates of background seismicity make it challenging to quantify the pace of landscape change and determine the likelihood and timing of fault movement that could raise and lower parts of the landscape and create associated geohazards.

To infer regional rates of denudation, we measured ${ }^{10} \mathrm{Be}$ in river sediment samples and found that south-central South Africa is eroding $\sim 5 \mathrm{~m} \mathrm{m.y.}{ }^{-1}$, a slow erosion rate consistent with those measured in other non-tectonically active areas, including much of southern Africa. To estimate the rate at which extensive, fossil, upland, silcrete-mantled pediment surfaces erode, we measured ${ }^{10} \mathrm{Be}$ and ${ }^{26} \mathrm{Al}$ in exposed quartzite samples. Undeformed upland surfaces are little changed since the Pliocene; some have minimum exposure ages exceeding 2.5 m.y. (median, 1.3 m.y.) and maximum erosion rates of $<0.2 \mathrm{~m} \mathrm{m.y.} .^{-1}$ (median, $0.34 \mathrm{~m}$ m.y. $\left.{ }^{-1}\right)$, consistent with no Quaternary movement on faults that displace the underlying quartzite but not the silcrete cover.

We directly dated a recent displacement event on the only recognized Quaternary-active fault in South Africa, a fault that displaces both silcrete and the underlying quartzite. The concentrations of ${ }^{10} \mathrm{Be}$ in exposed fault scarp samples are consistent with a $1.5 \mathrm{~m}$ displacement occurring ca. $25 \mathrm{ka}$. Samples from this offset upland surface have lower minimum limiting exposure ages and higher maximum erosion rates than those from undeformed pediment surfaces, consistent with Pleistocene earthquakes and deformation reducing overall landscape stability proximal to the fault zone.

Rates of landscape change on the extensive, stable, silcretized, upland pediment surfaces are an order of magnitude lower than basin-average erosion rates. As isostatic response to regional denudation uplifts the entire landscape at several meters per million years, valleys deepen, isolating stable upland surfaces and creating the spectacular relief for which the region is known.

\section{INTRODUCTION}

Southern Africa has long attracted the attention of geologists and geomorphologists (King, 1953; Partridge and Maud, 1987). This is a landscape of ancient rocks, some pervasively deformed, cropping out in what is now a cratonic setting (Brown et al., 2000). Some of the continental margin is bordered by steep escarpments separating broad, low-elevation coastal plains from higher elevation uplands. Fission track and cosmogenic isotope analysis both suggest the escarpments retreated quickly after rifting and are now stable forms eroding only slowly (Bierman and Caffee, 2001; Cockburn et al., 2000; Matmon et al., 2002; Tinker et al., 2008).

Large areas of southern Africa have been beveled by erosion, leaving low-gradient geomorphic surfaces (pediments) stretching in some places kilometers from the range front toward the center of wide valleys (King, 1953). Some geomorphologists have correlated these extensive fossil geomorphic surfaces in order to provide evidence for episodic uplift and denudation since rifting and the breakup of Gondwanaland (King, 1953; Partridge and Maud, 1987). Pediment surfaces are commonly incised by headward-eroding drainages (Fig. 1) and can become isolated from adjoining mountain fronts by stream incision.

Some pediment surfaces are capped by gravels that have in many places been cemented by pedogenic processes and are now lithified as silcretes, calcretes, and ferricretes (Summerfield, 1983). The age of these high gravels, which are mapped as the Grahamstown Formation (Tg), is not well constrained. Numerical ages are scarce (Partridge and Maud, 1987). Electron spin resonance analysis suggests a Miocene age (7.3 Ma and 9.4 Ma) for two silcrete caps on pediment remnants in the Little Karoo (Hagedorn, 1988) west of our field area.

There is limited seismic activity in South Africa although faults in rock are commonplace (Fig. 2). The age of fault offset is typically poorly constrained, making it difficult to estimate the likelihood, magnitude, duration, and aerial extent of seismic shaking. Most historical South African earthquakes have been small; there

GSA Today, v. 24, no. 9, doi: 10.1130/GSATG206A.1. 


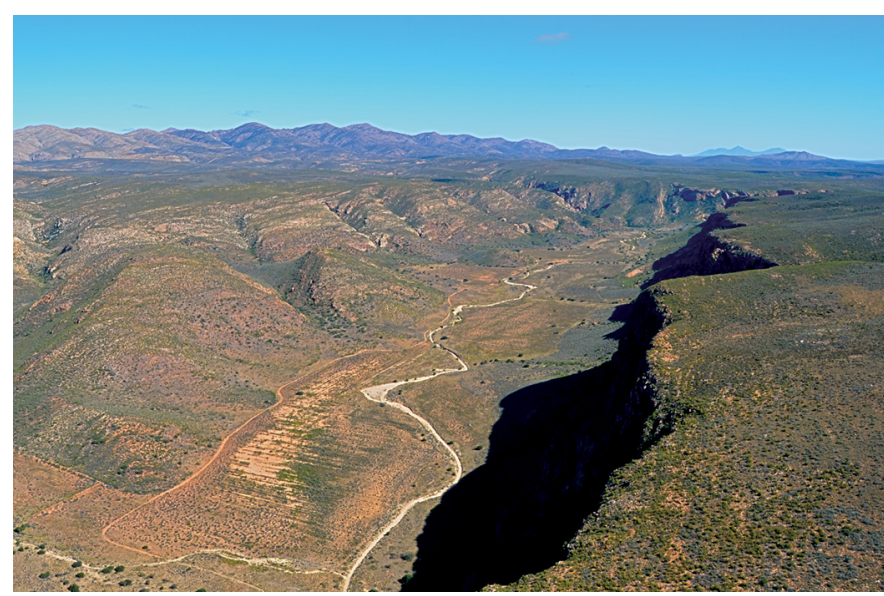

Figure 1. Deeply dissected landscape. Near river sediment sample site TSP17, the Baviaanskloof River is incised $>100 \mathrm{~m}$ into the gently sloping, dissected silcrete-capped pediment from which we collected surface samples (TSP15 and TSP16, right side of image). Location $33^{\circ} 31^{\prime} 8.4^{\prime \prime} \mathrm{S}, 23^{\circ} 38^{\prime} 27.6^{\prime \prime}$ E (WGS 84). Field of view in front of image is $\sim 3-\mathrm{km}$-wide, looking west (shown on Fig. 3A).

have been only a few moderate intensity quakes including the 1969 Ceres quake $\left(\mathrm{M}_{\mathrm{W}}\right.$ 6.2) in the Western Cape region and the 1920 and 1976 Koffiefontein $M_{W} 6.2$ and 5.8 quakes in central South Africa (Bommer et al., 2013).

Surface offsets are rare (Hill, 1988). The Kango Fault, which is the only recognized Quaternary-active fault in South Africa (Hill, 1988), is part of the continent-wide Ceres-Kango-BaviaanskloofCoega and Kouga Fault system that extends $>600 \mathrm{~km}$ from near Cape Town in the west to Port Elizabeth in the east (Fig. 2). There are surface fault scarps along as much as $84 \mathrm{~km}$ of the eastern half of the Kango Fault, and trenching investigations at two sites in the western part of this reactivated segment document the occurrence of two large-magnitude earthquakes within the past 10-15 k.y. (Bommer et al., 2013). The extent of the surface rupture during these earthquakes and the timing of the most recent surface rupturing event on the eastern part of the reactivated Kango Fault are not well constrained. Surface offsets recorded in high geomorphic surfaces capped by cemented gravels (Tg) demonstrate that there have been previous episodes of probable Quaternary faulting along this eastern part. Similar gravel-capped pediment surfaces (which are not offset) locally extend across other faults within the fault system.

Cosmogenic isotopes produced in situ have been used in Africa to estimate rates of erosion (Bierman and Caffee, 2001; Chadwick et al., 2013; Scharf et al., 2013), exposure ages of rock surfaces (Shanahan and Zreda, 2000), and the near-surface burial and exposure history of rock, soil, and sediment (Erlanger et al., 2012). Measurements of paired isotopes with different half-lives (such as ${ }^{26} \mathrm{Al}$ and ${ }^{10} \mathrm{Be}$ ) can be used to determine whether a sample was exposed and then buried before being re-exposed (Granger and Muzikar, 2001). Measurements of cosmogenic ${ }^{21} \mathrm{Ne}$ elsewhere in southern Africa demonstrate that gravels capping some ancient erosion surfaces are extremely old with some having Pliocene ages (Van der Wateren and Dunai, 2001).

In this paper, we present new isotopic data from semi-arid to sub-humid south-central South Africa, an area characterized by exposed bedrock, ephemeral streams, and hilly to mountainous terrain. Measurements of ${ }^{10} \mathrm{Be}$ and ${ }^{26} \mathrm{Al}$ support the antiquity (at least Pliocene age) of the widespread planar pediment surfaces and the young age (Late Pleistocene) of a fault scarp on the eastern part of the reactivated segment of the Kango Fault. We use this chronologic information to establish limits on the timing of offset on major, through-going regional faults. We show that the regional erosion rate, while low and consistent with a tectonically inactive cratonic setting, is still many times higher than the rate of pediment erosion; thus, local relief is growing over time.

\section{SAMPLING SITES AND METHODS}

We collected eight sand samples from river channels draining seven basins in south-central South Africa in order to estimate basin-average erosion rates and infer rates of isostatically driven rock uplift (Figs. 2, 3A, and 3B). Some of the larger streams and those sourced closer to the coast have perennial flow; others flow intermittently. In the Cape Fold Belt Mountains, $\sim 75 \mathrm{~km}$ inland, we collected, from low-gradient, beveled quartzite pediment surfaces, loose surface cobbles and samples from outcropping boulders embedded in the meters-thick silcrete that completely covers bedrock (Figs. 3C, 3D, and 3E). The surfaces are vegetated with grass and shrubs and slope gently (at most several degrees) away from nearby mountain fronts. The silcrete surfaces overlying four bedrock faults are not offset by faulting (TSP12, 14, 16, 17); thus, they
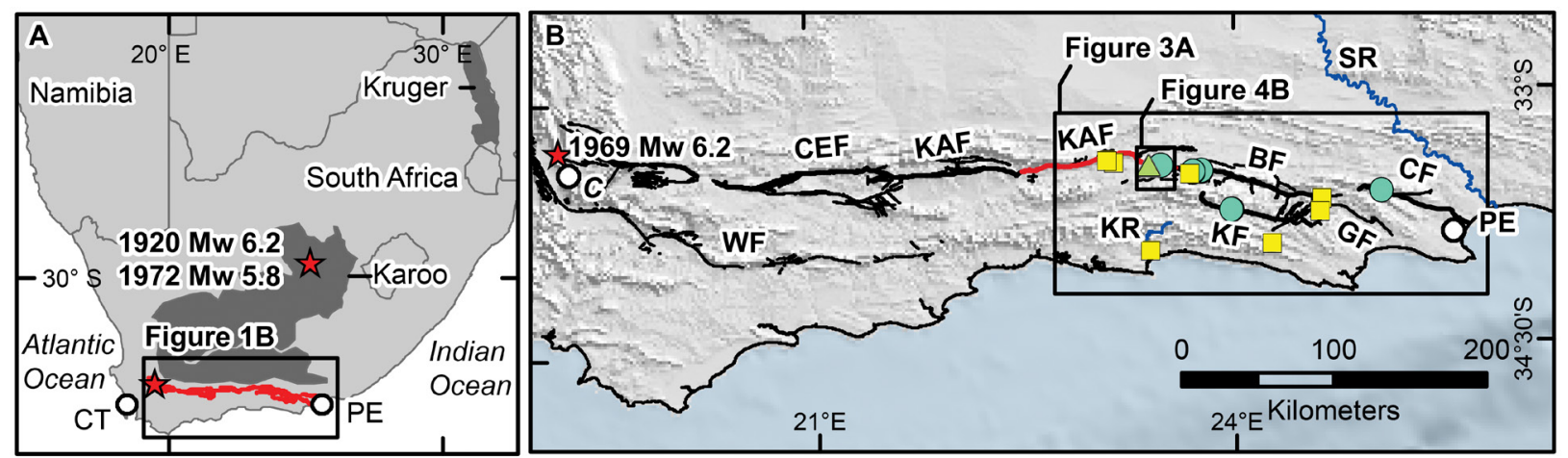

Figure 2. Location maps. (A) Regional context. (B) Sample sites and faults. Dark gray—Karoo and Kruger National Park; red line—Ceres-Kango-BaviaanskloofCoega Fault System. Green circles—pediment samples; green triangle—fault scarp sample site; red stars—historical earthquakes; yellow squares—sediment samples. BF-Baviaanskloof Fault; C—Ceres; CEF—Ceres Fault; CF-Coega Fault; CT—Cape Town; GF—Gamtoos Fault; KAF-Kango Fault (Quaternaryreactivated segment shown in red); KF—Kouga Fault; KR—Keurbooms River; PE—Port Elizabeth; SR—Sundays River; WF-Worcester Fault. 

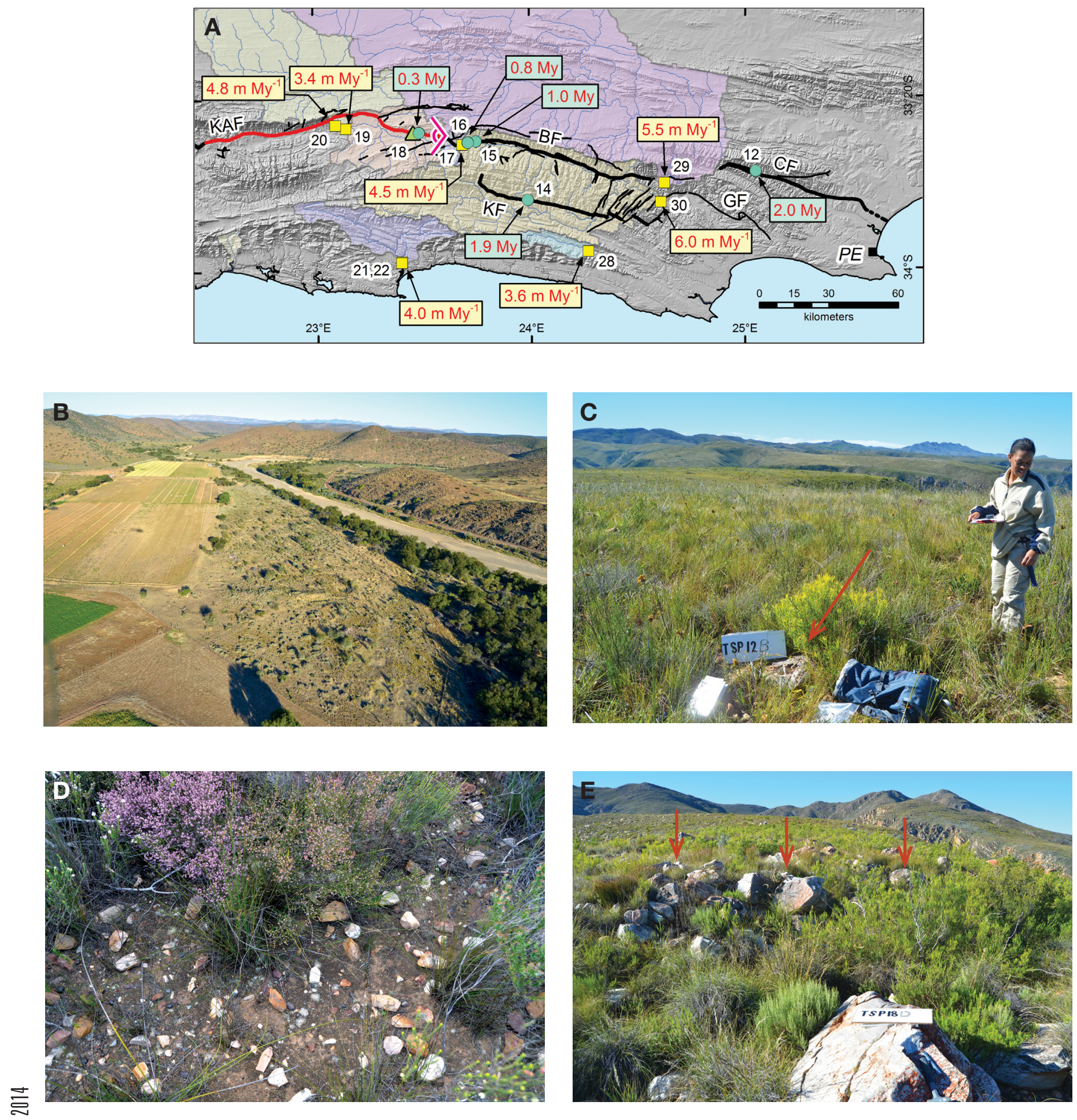

Figure 3. Sampling sites. (A) Sample location map with minimum limiting ages for pediment samples (green) and erosion rates for river samples (yellow). TSP sample sites identified by number; drainage basins shaded. BF—Bavianskloof Fault; CF—Coega Fault; GF-Gamtoos Fault; KAF-Kango Fault (Quaternaryreactivated segment shown in red); KF-Kouga Fault; PE-Port Elizabeth. (B) View down toward Traka River sample site TSP20 (basin area 3066 km²; erosion rate, $4.8 \mathrm{~m} \mathrm{~m} . \mathrm{y}^{-1}$ ) showing an ephemeral river and alluvial valley. (C) Site TSP12B shown by arrow is a quartzite boulder embedded in and cropping out from vegetated silcrete surface (min. ${ }^{10} \mathrm{Be}$ exposure age 1.8 m.y.). Min. total history considering ${ }^{10} \mathrm{Be}$ and ${ }^{26} \mathrm{Al}: 3.0$ m.y. (D) Loose clasts on the surface at TSP14; range of clast min. ${ }^{10}$ Be exposure ages is 1.3-1.8 m.y. (E) Sample site TSP18D, an outcropping quartzite boulder embedded in silcrete (min. exposure age: 0.36 m.y.). Arrows point to the main fault scarp bounding the graben on the hanging wall (see Fig. 4B). 
provide a datum for determining a minimum limit for when the bedrock fault beneath last slipped. One pediment surface and its silcrete cover are offset by the trace of the Kango Fault (TSP18; Fig. 4A). Fault scarp samples (TSP18B) were collected from the hard, southward-facing silcrete face of the main fault scarp along the western edge of the pediment (Figs. $4 \mathrm{~B}$ and $4 \mathrm{C}$ ); one sample was collected from the flat-lying pediment surface just above the scarp face. Samples were processed at the University of Vermont, analyzed at Lawrence Livermore National Laboratory, and the CRONUS online calculator was used for age and erosion rate calculations. Detailed methods for sampling, sample preparation, and data analysis are provided in the online data repository along with data tables (Tables S1-S5; see GSA Supplemental Data' ${ }^{1}$.

\section{PEDIMENT SURFACE MINIMUM LIMITING AGES}

Outcropping boulders embedded in the silcrete and loose clasts from South African pediment surfaces (supplemental data Table S5 [see footnote 1]) contain exceptionally high concentrations of in situ-produced ${ }^{10} \mathrm{Be}$ (up to $9.9 \times 10^{6}$ atoms $\mathrm{g}^{-1}$ ) and ${ }^{26} \mathrm{Al}$ (up to $3.9 \times 10^{7}$ atoms $\mathrm{g}^{-1}$ ). These ${ }^{10} \mathrm{Be}$ concentrations can be interpreted as minimum durations of surface exposure (assuming rapid exposure and no burial or erosion since exposure) of 0.2-2.7 m.y. (median $=0.93$ m.y.) or as maximum limiting erosion rates of 0.11-3.2 m m.y. ${ }^{-1}$ (median $=0.54 \mathrm{~m} \mathrm{m.y.}{ }^{-1}$ ), assuming steady erosion of at least several meters of material from the pediment surface. Field evidence does not allow us to differentiate between these two interpretations, but both are indicative of exceptional surface stability over time.

Sample TSP18A2, shielded from cosmic rays by several meters of silcrete, has low concentrations of both ${ }^{26} \mathrm{Al}\left(2.9 \times 10^{5}\right.$ atoms $\left.\mathrm{g}^{-1}\right)$ and ${ }^{10} \mathrm{Be}\left(4.1 \times 10^{4}\right.$ atoms $\left.\mathrm{g}^{-1}\right)$ and has $\mathrm{a}^{26} \mathrm{Al} /{ }^{10} \mathrm{Be}$ ratio $(7.03 \pm 0.65$, $1 \sigma$ analytical uncertainty) that is indistinguishable from the surface ${ }^{26} \mathrm{Al} /{ }^{10} \mathrm{Be}$ production ratio. We interpret these data as indicating that most of the ${ }^{10} \mathrm{Be}$ and ${ }^{26} \mathrm{Al}$ inherited from surface exposure before deposition on the pediment long ago has decayed away; thus, clasts now incorporated in the silcrete were deposited at least several ${ }^{10} \mathrm{Be}$ half-lives ago $\left({ }^{10} \mathrm{Be}\right.$ half-life $\sim 1.4$ m.y. $)$. Not only does the low nuclide concentration in TSP18A2 suggest that pediment-capping, silcretized gravels predate the Pleistocene, but the low concentration of ${ }^{10} \mathrm{Be}$ in TSP18A2 indicates that the cosmogenic radionuclide concentrations measured in the surface clasts and outcrops we sampled reflect exposure on the pediment rather than in the mountainous source catchments.

Considering the ${ }^{26} \mathrm{Al}$ analyses along with the ${ }^{10} \mathrm{Be}$ analyses suggests that most samples have experienced little if any burial since initial exposure (Fig. 5A); only one of the eight samples for which both nuclides were measured lies below the surface exposure region of the two-isotope plot when $2 \sigma$ uncertainties are considered. These data suggest that the pediment surfaces we sampled have simple histories that reflect long-term exposure and slow erosion with scant burial by soil or wind-blown sediment (cf. Nishiizumi et al., 1991). Considering both ${ }^{10} \mathrm{Be}$ and ${ }^{26} \mathrm{Al}$ concentrations, minimum total histories of samples (initial exposure plus burial; Bierman et al., 1999) collected from the unfaulted surfaces range between 1.0 and 3.7 m.y. (Table S5 [see footnote 1]).
The two-isotope data provide a third line of evidence that some of these surfaces have been stable near Earth's surface since at least the Pliocene.

The oldest or most slowly eroding samples were taken from outcropping boulders embedded in silcrete (e.g., TSP12A, 2.7 m.y., $\left.0.11 \mathrm{~m} \mathrm{~m} . \mathrm{y}^{-1}\right)$, and the mean exposure age of boulder samples $(1.27 \pm 0.84$ m.y. $)$ is higher than the mean exposure age of cobble samples $(0.93 \pm 0.54$ m.y.); however, the populations of minimum limiting surface exposure ages for cobbles and outcropping boulders are not separable statistically (Student's $t$-Test); thus, we consider them together to estimate the minimum surface age and maximum erosion rate for each sampled surface.

The five sampled surfaces have different and in some cases statistically distinguishable minimum surface exposure ages and maximum erosion rates. An analysis of variance (Fig. 5B) shows that significant differences exist between the surfaces; eastern sites TSP12 and TSP14 have minimum surface exposure ages that are greater and maximum erosion rates that are less than those calculated for western sites TSP15 and TSP16. Site TSP18, cut by a fault scarp, has surface exposure ages significantly less than and erosion rates greater than that of all four other surfaces. Surface stability decreases to the west (Fig. 3A).

\section{FAULT SCARP EXPOSURE AGE}

Vertical offset on the Kango Fault is clearly visible for kilometers along strike both in rock and in overlying silcrete (Fig. 4A). At sample site TSP18, the pediment surface is offset vertically a total of 5-7 $\mathrm{m}$ by a series of en echelon faults (Fig. 4B). The most recent ruptures left a several-meter-high scarp in cemented silcrete; the bottom $1.5 \mathrm{~m}$ of the scarp are vertical, the silcrete is very hard, and the scarp appears well preserved, reflecting what we interpret to be movement during the last rupture event on this part of the reactivated fault (Fig. 4C). Above the $1.5 \mathrm{~m}$ scarp is a sub-horizontal surface of hard silcrete, part of the pediment.

The measured concentration of ${ }^{10} \mathrm{Be}$ decreases exponentially down the scarp (Fig. 4D and Table S4 [see footnote 1]). In order to determine the age of faulting, we used the concentration of ${ }^{10} \mathrm{Be}$ measured in sample TSP18B0, collected on the horizontal surface above the scarp face and the ${ }^{10} \mathrm{Be}$ production rate at the site, to calculate the expected concentration of ${ }^{10} \mathrm{Be}$ with depth below the surface had faulting not occurred (Fig. 4D and supplementary material). We then compared the calculated and measured concentrations of ${ }^{10} \mathrm{Be}$. All four fault plane samples (TSP18B3, 6, 9, and 12), independent of their depth below the surface, contained $1.15 \pm 0.11 \times 10^{5}$ atoms $\mathrm{g}^{-1}$ more ${ }^{10} \mathrm{Be}$ than predicted by the model. We interpret this uniform excess concentration as ${ }^{10} \mathrm{Be}$ produced by cosmic rays striking the fault scarp directly after it was exposed by surface rupture during an earthquake (Fig. 4D).

Knowing the production rate of ${ }^{10} \mathrm{Be}$ on the fault scarp allows us to calculate the age of the displacement using different assumptions about the stability of the silcrete edge that truncates the sampled scarp to the west (see supplementary material [footnote 1]). If we assume that the western edge of the silcrete (perpendicular to the scarp) is rapidly eroding and no ${ }^{10} \mathrm{Be}$ was produced in our samples by neutrons penetrating from the west (Fig. 4C),

${ }^{1}$ GSA supplemental data item 2014246, detailed methods and data tables, is online at www.geosociety.org/pubs/ft2014.htm. You can also request a copy from GSA Today, P.O. Box 9140, Boulder, CO 80301-9140, USA; gsatoday@geosociety.org. 
the scarp was formed by an earthquake ca. $25.4 \pm 2.6 \mathrm{ka}$ (uncertainty represents $1 \sigma$ of difference between observed and modeled ${ }^{10}$ Be measured in TSP18B3, 6, 9, and 12). If we assume that the stability of the silcrete edge is similar to sample TSP18B0, then the scarp formed ca. $23.6 \pm 2.6 \mathrm{ka}$.

The similarity of the model ages generated from samples TSP18-B3, 6, 9, and 12 (Table S4 [see footnote 1]) is most consistent with a single event scarp; there is no systematic change in the difference between the measured and modeled ${ }^{10} \mathrm{Be}$ concentration with depth below the surface (Fig. 4D). Nor is there any field or isotopic indication that colluvium near the base of the scarp has been recently eroded. If such erosion had occurred, we would observe less difference between the measured and modeled ${ }^{10} \mathrm{Be}$ concentrations at the base of the scarp than high on the scarp; this is not the case (Fig. 4D).

\section{RIVER SEDIMENT, BASIN-AVERAGE EROSION RATES, AND EROSION-DRIVEN UPLIFT}

Concentrations of ${ }^{10} \mathrm{Be}$ in eight river sand samples from southcentral South African drainage basins of differing size are similar
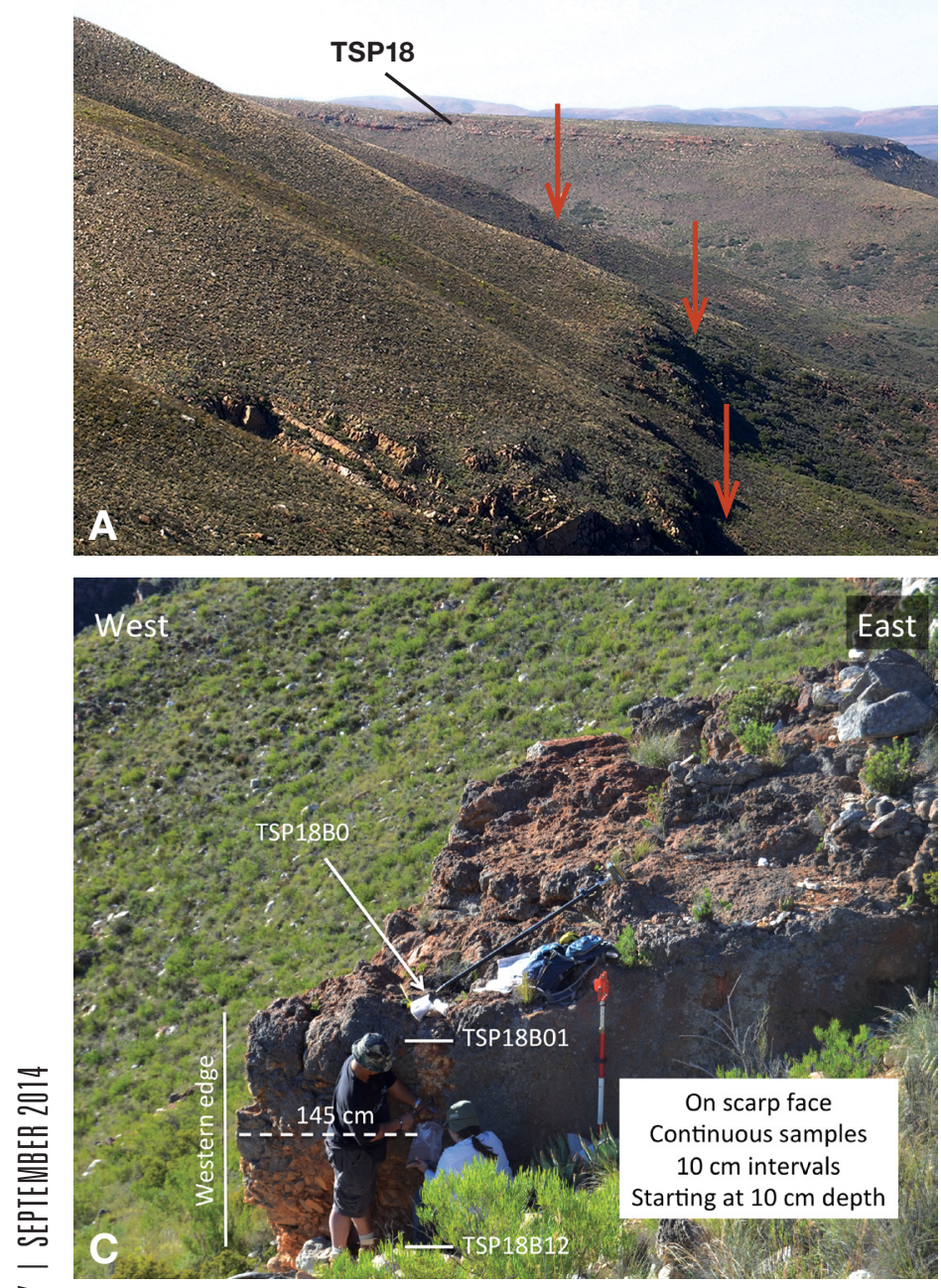

and high $\left(0.84-1.53 \times 10^{6}\right.$ atoms $\mathrm{g}^{-1}$; Table S3 [see footnote 1]). Two samples (TSP21 and TSP22), collected from sand bars $\sim 450 \mathrm{~m}$ apart on the Keurbooms River, have the same ${ }^{10} \mathrm{Be}$ concentration within measurement uncertainty $\left(1.03\right.$ and $1.04 \times 10^{6}$ atoms $\mathrm{g}^{-1}$; Table S2), indicating that ${ }^{10} \mathrm{Be}$ measurements of river sediment are reproducible and that sediment in the Keurbooms River is well mixed.

For the eight samples we collected, basin-average erosion rates range from 3.4 to $6.0 \mathrm{~m} \mathrm{m.y.}{ }^{-1}$. Not considering the two nested samples (TSP17 and TSP21 are upstream of TSP30 and TSP22, respectively), the area-weighted average erosion rate for the southcentral coastal region of South Africa is $5.4 \mathrm{~m} \mathrm{m.y.}{ }^{-1}(n=6)$, indistinguishable from the median of 10 smaller catchments $(5.2 \mathrm{~m}$ m.y. ${ }^{-1}$ ) nearby (Scharf et al., 2013). This erosion rate represents a spatial and temporal integration over the time it takes to remove several meters of rock from Earth's surface-in this case, several hundred thousand years.

Basin average erosion rates are not clearly related to watershed characteristics (Table S3 [see footnote 1]). There are no statistically significant relationships between basin average erosion rate
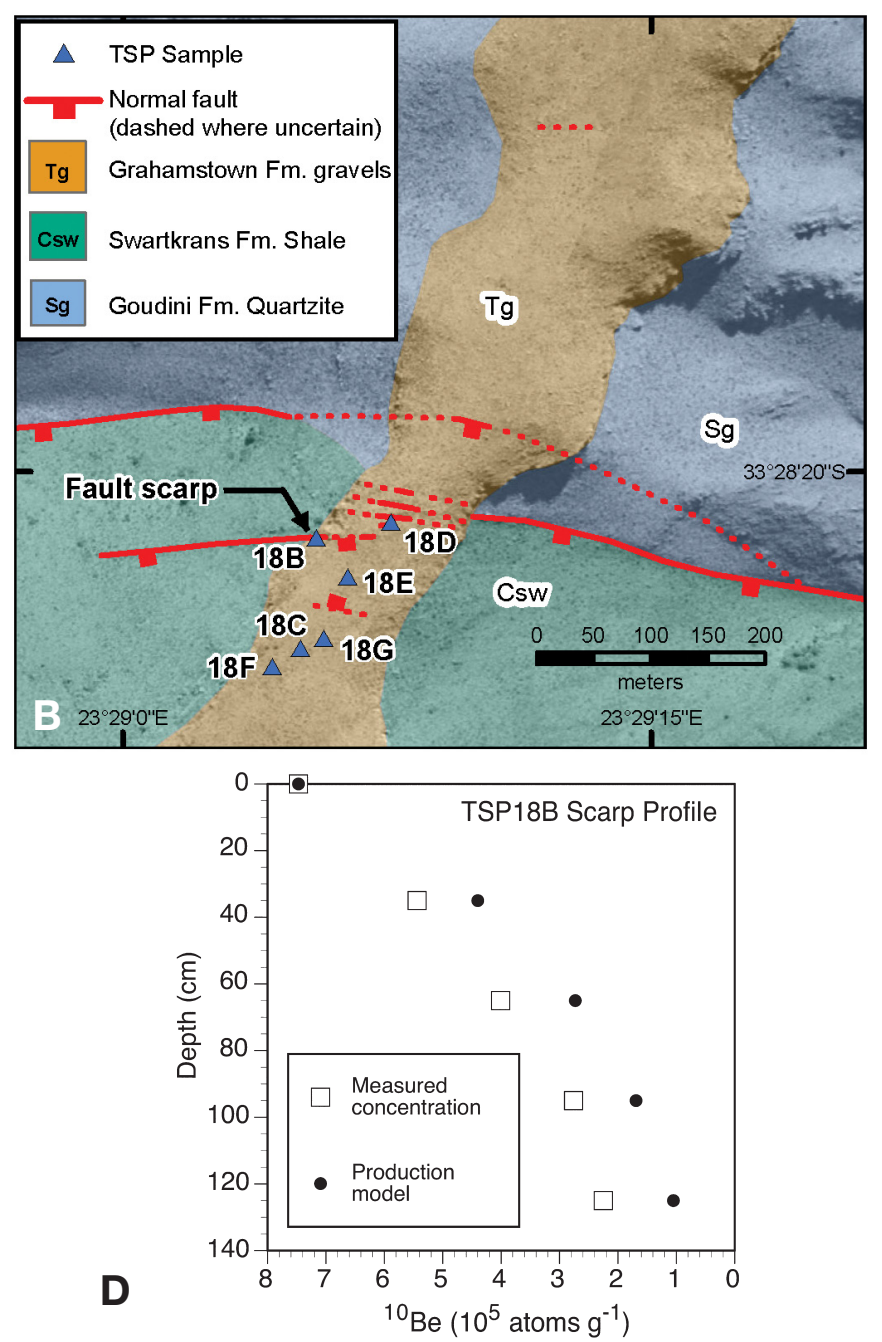

Figure 4. Fault scarp in silcrete. (A) Looking east along range front toward site TSP18; red arrows show fault scarp (photo by J. McCalpin). (B) Map of fault traces that disrupt Tg surface and sampled scarp locality at TSP18. (The Swartkrans Formation is equivalent to the Voorstehoek Formation, Ceres Group.) (C) Fault scarp sampling for cosmogenic nuclide analysis at site TSP18. View from the south. (D) ${ }^{10} \mathrm{Be}$ depth profile from fault scarp (exposed fault plane) showing measured concentration (open squares) and concentrations modeled assuming exponential decline in ${ }^{10} \mathrm{Be}$ production below surface sample TSP18B0. The concentration difference between the model and the measured value reflects nuclide production after faulting exposed the scarp. 

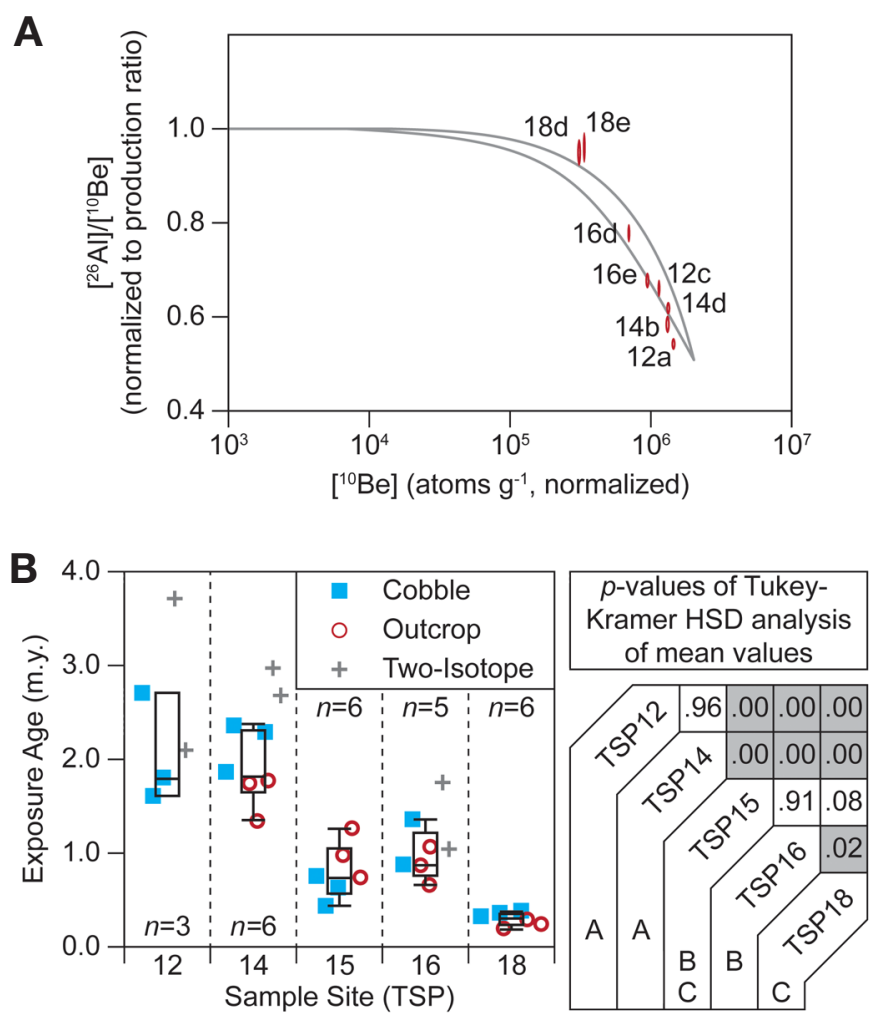

Figure 5. Pediment sample results. (A) Two-isotope plot for outcrop samples collected from the four pediment surfaces (TSP12, 14, 16, and 18); 10 analytical uncertainties plotted. (B) Results of analysis of variance showing min. limiting surface exposure ages $\left({ }^{10} \mathrm{Be}\right)$ for cobble samples (blue squares) and outcropping boulder samples (red circles) collected from five pediment surfaces; twoisotope total histories for boulders are also shown (gray crosses). Bar and whisker plots of ${ }^{10} \mathrm{Be}$ data show median as horizontal line; box encloses second and third quartiles; whiskers show range of data (the remaining data points are outliers). Results from Tukey-Kramer HSD analysis show statistical similarity (same letter) or statistical difference (different letter) of means of sample populations $(p<0.05$ [shaded gray boxes]).

and basin average slope $\left(\mathrm{R}^{2}=0.01 ; p=0.84\right)$, mean basin elevation $\left(\mathrm{R}^{2}=0.11 ; p=0.51\right)$, mean annual precipitation $\left(\mathrm{R}^{2}=0.20\right.$; $p=0.38)$, basin area $\left(\mathrm{R}^{2}=0.29 ; p=0.27\right)$, or basin elevation range (a proxy for relief, $\mathrm{R}^{2}=0.49 ; p=0.12$ ).

\section{DISCUSSION}

Measurements of in situ-produced cosmogenic ${ }^{10} \mathrm{Be}$ and ${ }^{26} \mathrm{Al}$ place quantitative, geochronologic constraints on the history of land surfaces in south-central South Africa. The data constrain erosion rates in the field area, the minimum age of geomorphic surfaces, the Quaternary history of faults, and the rate at which rock uplift, in response to surface denudation, is likely occurring.

The central South African landscape is exceptionally stable. Pediment and basin-average erosion rates, when compared to the global compilation of Portenga and Bierman (2011), are among the slowest in the world (Fig. 6). The sampled drainage basins rank between 10th and 42nd out of 1,003 sites listed in Portenga and Bierman (2011), whereas the outcropping boulders and pediment surface clasts have erosion rates comparable to the lowest fifth of bedrock outcrop erosion rates, ranking fourth to 82nd out of 490 samples. Such stability is likely caused by the resistance to erosion of massive quartzite and the well-indurated silcrete that

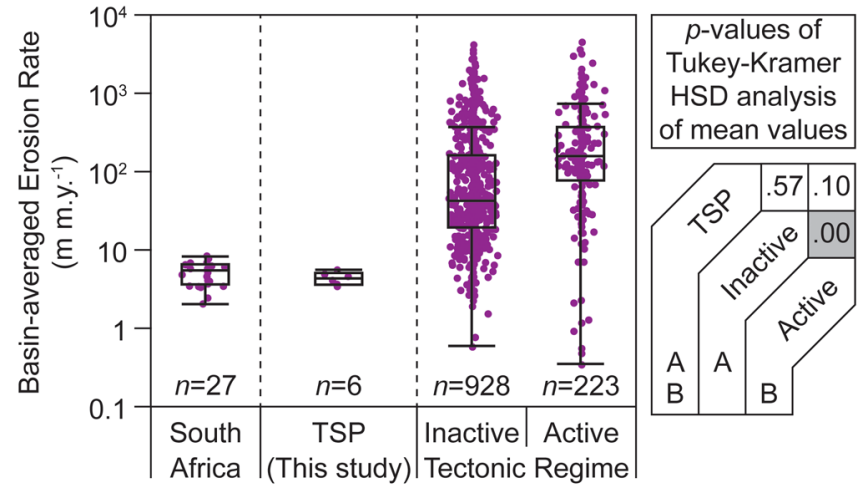

Figure 6. Erosion rate comparison. Semi-log bar and whisker plots showing global data set of basin-average erosion rates inferred from ${ }^{10} \mathrm{Be}$ in river sand (purple dots, Portenga and Bierman, 2011) compared to TSP data from this study and other measurements from South Africa (Scharf et al., 2013; Chadwick et al., 2013). Data from this study are consistent with data from areas defined as not tectonically active (peak ground acceleration $>2 \%$ g with a $10 \%$ probability in $50 \mathrm{yr}$; Giardini et al., 1999) and are indistinguishable from other South African data.

caps the surfaces and encases cobbles (Bierman and Caffee, 2002; Scharf et al., 2013). Similarly low rates of erosion have been reported for outcrops of dolerite to the north in the Karoo (Decker et al., 2013).

Both the outcrop and basin-average erosion rates measured in south-central South Africa are most consistent with data from non-tectonically active areas along passive margins, including central and southern Australia (Bierman et al., 1998; Heimsath et al., 2001), Namibia (Bierman and Caffee, 2001), the Sri Lankan escarpment (Vanacker et al., 2007), and parts of the Appalachian Mountains (Duxbury et al., 2007). At a drainage basin scale, the landscape of south-central South Africa appears to be eroding at a rate similar to central Namibia (8 m m.y. ${ }^{-1}$; Bierman et al., 2007) and Kruger National Park (5.5 m m.y. ${ }^{-1}$; Chadwick et al., 2013) to the east but more slowly than other parts of eastern South Africa (27 m m.y. ${ }^{-1}$; Erlanger, 2010).

Surface erosion and the consequent export of mass from the continent to the Indian Ocean triggers isostatic uplift because there is very little long-term sediment storage in the field area. Considering the low rates of erosion we measured at a basin scale

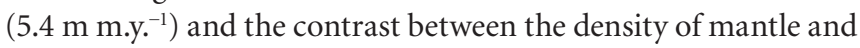
continental rock (3.3 versus $2.7 \mathrm{~g} \mathrm{~cm}^{-3}$ ), the long-term, average erosionally driven isostatic rock uplift rate in central southern Africa is $4.4 \mathrm{~m} \mathrm{m.y.}{ }^{-1}$. This is a lower rate of uplift than that inferred for the Sundays River area to the east (9-16 m m.y. ${ }^{-1}$; Erlanger et al., 2012).

Samples collected from four unfaulted, silcrete-capped pediment surfaces, under which run the traces of the Kouga, Baviaanskloof, and Coega Faults, contain high concentrations of ${ }^{10} \mathrm{Be}$ in both outcropping boulders embedded in the silcrete and in loose clasts collected from the surfaces - in many cases, equivalent to at least millions of years of surface exposure. Because these pediment surfaces are so stable, if there had been any Pleistocene offset, fault scarps should be visible on the landscape. The absence of such scarps and the absence of offset on the basal silcrete/bedrock contact observed locally suggest that the Kouga, Baviaanskloof, and Coega Faults are not currently active and have not been active since deposition of the silcrete, most likely in the Miocene. 
The lack of fault offset on the ancient surfaces constrains Quaternary fault motion to a restricted area $(\sim 100 \mathrm{~km})$ on the western section of the Kango-Coega Fault system, where there is strong evidence for geologically recent surface rupture. The latest rupture at TSP18 appears to have occurred in the Late Pleistocene, between 20 and $25 \mathrm{ka}$. This offset is older than that documented in alluvial deposits at 60 and $75 \mathrm{~km}$ along strike to the west (Goedhart and Booth, 2009; Hanson et al., 2014). There, two surface-rupturing events in the past $10-15 \mathrm{k} . \mathrm{y}$. were preceded by a long period of seismic quiescence (Bommer et al., 2013). The difference in displacement time along strike suggests that the Kango Fault ruptures in segments during at least some events.

Surface stability, as expressed by the concentration of cosmogenic nuclides in surface materials, increases away from the reactivated Kango Fault. The lowest surface exposure ages were measured on the faulted surface (TSP18), consistent with seismic activity (shaking and surface displacement), increasing the rate at which the surface erodes. The relatively low concentrations of cosmogenic nuclides measured in both outcropping boulders and surface clast samples at TSP18 suggest that faulting has affected the surface for at least several hundred thousand years-a sufficient duration to lower its long-term stability. Surfaces more distant from the active fault zone (TSP15 and TSP16) have minimum surface exposure ages that are lower by a factor of two than the most stable surfaces (TSP12 and TSP14), which are even farther away. If surface stability is related to faulting, then longterm fault activity and the likelihood of seismic shaking decreases from west to the east along the sampled area of the fault system.

Erosion of the central South African landscape is not spatially uniform. The aerially extensive pediment surfaces are eroding nearly an order of magnitude more slowly than the landscape as a whole - these are stable, nearly fossil uplands. The very low erosion rates of most pediment surfaces (decimeters per million years) have allowed them to persist for at least millions of years, almost certainly because they are underlain by hard, non-reactive quartzite and covered by silica-cemented quartzite gravels.

The disparity between the rate of pediment surface lowering (decimeters per million years) and the rate of landscape lowering (meters per million years) suggests that local relief is growing, albeit slowly, over time; however, the lack of a relationship between average drainage basin slope and erosion rate (Riebe et al., 2000) suggests that long-term, average base-level in the study area has not changed - an indication of tectonic stability (i.e., the lack of abrupt uplift between the sampled basins and the Indian Ocean, which provides the ultimate base-level for these drainages). We speculate that the incision of the erosion-resistant pediments results from ongoing isostatic adjustment (cratonic uplift) as mass is shifted off the craton and delivered to the Indian Ocean, allowing the cutting of deep, pediment-dissecting canyons. Although much of the isostatic adjustment is likely accomplished by crustal warping (Pazzaglia and Gardner, 1994), normal faults, such as the Kango fault system, are another mechanism by which the craton could be differentially uplifted locally in response to net mass removal by erosion and transport offshore.

\section{ACKNOWLEDGMENTS}

Work presented in this paper was conducted as a part of the probabilistic seismic hazard analysis for the Thyspunt site conducted by the Council for Geoscience under contract from Eskom, the South African state-owned energy utility. We thank many who helped with sample collection, analysis, interpretation, and project management, including A.P. Nel, E. Hattingh, K.J. Coppersmith, M. Goedhart, J. McCalpin, L. Glaser, T. Brown, S. Zimmerman, R. Finkel, and G. Balco. We also thank A. Heimsath and an anonymous reviewer.

\section{REFERENCES CITED}

Bierman, P.R., and Caffee, M.W., 2001, Slow rates of rock surface erosion and sediment production across the Namib Desert and escarpment, Southern Africa: American Journal of Science, v. 301, no. 4-5, p. 326-358, doi: 10.2475/ajs.301.4-5.326.

Bierman, P.R., and Caffee, M., 2002, Cosmogenic exposure and erosion history of ancient Australian bedrock landforms: GSA Bulletin, v. 114, no. 7, p. 787-803, doi: 10.1130/0016-7606(2002)114<0787:CEAEHO>2.0.CO;2.

Bierman, P.R., Albrecht, A., Bothner, M., Brown, E., Bullen, T., Gray, L., and Turpin, L., 1998, Weathering, erosion and sedimentation, in Kendall, C., and McDonnell, J.J., eds., Isotope Tracers in Catchment Hydrology: Amsterdam, Elsevier, p. 647-678.

Bierman, P.R., Marsella, K.A., Patterson, C., Davis, P.T., and Caffee, M., 1999, Mid-Pleistocene cosmogenic minimum-age limits for pre-Wisconsinan glacial surfaces in southwestern Minnesota and southern Baffin Island; a multiple nuclide approach: Geomorphology, v. 27, no. 1-2, p. 25-39, doi: 10.1016/S0169-555X(98)00088-9.

Bierman, P.R., Nichols, K.K., Matmon, A., Enzel, Y., Larsen, J., and Finkel, R., 2007, 10-Be shows that Namibian drainage basins are slowly, steadily and uniformly eroding: Quaternary International, v. 167-168, no. 3, p. 33.

Bommer, J.J., Coppersmith, K.J., Coppersmith, R.T., Hanson, K.L., Mangongolo, A., Neveling, J., Rathje, E.M., Rodriguez-Marek, A., Scherbaum, F., Shelembe, R., Stafford, P.J., and Strasser, F.O., 2013, A SSHAC level 3 probabilistic seismic hazard analysis for a new-build nuclear site in South Africa: Earthquake Spectra, doi: 10.1193/ 060913EQS145M.

Brown, R., Gallagher, K., Gleadow, A.J.W., and Summerfield, M.A., 2000, Morphotectonic evolution of the South Atlantic margins of Africa and South America, in Summerfield, M.A., ed., Geomorphology and Global Tectonics: Chichester, Wiley, p. 257-283.

Chadwick, O.A., Roering, J.J., Heimsath, A.M., Levick, S.R., Asner, G.P., and Khomo, L., 2013, Shaping post-orogenic landscapes by climate and chemical weathering: Geology, v. 41, no. 11, p. 1171-1174, doi: 10.1130/ G34721.1.

Cockburn, H.A.P., Brown, R.W., Summerfield, M.A., and Seidl, M.A., 2000, Quantifying passive margin denudation and landscape development using a combined fission-track thermochronology and cosmogenic isotope analysis approach: Earth and Planetary Science Letters, v. 179, no. 3-4, p. 429-435, doi: 10.1016/S0012-821X(00)00144-8.

Decker, J.E., Niedermann, S., and de Wit, M.J., 2013, Climatically influenced denudation rates of the southern African plateau: Clues to solving a geomorphic paradox: Geomorphology, v. 190, p. 48-60, doi: 10.1016/ j.geomorph.2013.02.007.

Duxbury, J., Bierman, P.R., Pavich, M., Southworth, S., Matmon, A., Larsen, J., and Finkel, R.C., 2007, Using cosmogenic isotopes to interpret landscape change in National Parks: Geological Society of America Abstracts with Programs, v. 39, no. 6, p. 378.

Erlanger, E.D., 2010, Rock uplift, erosion, and tectonic uplift of South Africa determined with cosmogenic ${ }^{26} \mathrm{Al}$ and ${ }^{10} \mathrm{Be}$ [M.Sc. Thesis]: West Lafayette, Indiana, Purdue University, $196 \mathrm{p}$.

Erlanger, E.D., Granger, D.E., and Gibbon, R.J., 2012, Rock uplift rates in South Africa from isochron burial dating of fluvial and marine terraces: Geology, v. 40, no. 11, p. 1019-1022, doi: 10.1130/G33172.1.

Giardini, D., Grunthal, G., Shedlock, K.M., and Zhang, P., 1999, The GSHAP Global Seismic Hazard Map: Annali di Geofisica, v. 42, no. 6, p. 1225-1230.

Goedhart, M.L., and Booth, P.W.K., 2009, Early Holocene extensional tectonics in the south-eastern Cape Fold Belt, South Africa, in Proceedings Ancient Rocks to Modern Techniques, 11th South African Geophysical Association (SAGA) Biennial Technical Meeting and Exhibition, Inkaba yeAfrica Phase II workshop, Manzini, Swaziland. 
Granger, D.E., and Muzikar, P.F., 2001, Dating sediment burial with in situproduced cosmogenic nuclides; theory, techniques, and limitations: Earth and Planetary Science Letters, v. 188, no. 1-2, p. 269-281, doi: 10.1016/ S0012-821X(01)00309-0.

Hagedorn, J., 1988, Silcretes in the Western Little Karoo and their relation to geomorphology and palaeoecology: Palaeoecology of Africa, v. 19, p. 371-375.

Hanson, K., Slack, C., Coppersmith, R., Neveling, J., Glaser, L., Bierman, P., Forman, S., Goedhart, M., Johnson, C., and Black, D., 2014, Paleoseismological Investigations of the Kango fault, South Africa: Incorporating temporal and spatial clustering behaviour into a seismic source characterization model (abs.): Seismological Research Letters, v. 85 , p. 548.

Heimsath, A.M., Chappell, J., Dietrich, W.E., Nishiizumi, K., and Finkel, R.C., 2001, Late Quaternary erosion in southeastern Australia: A field example using cosmogenic nuclides: Quaternary International, v. 83-85, p. 169-185, doi: 10.1016/S1040-6182(01)00038-6.

Hill, R.S., 1988, Quaternary faulting in the south-eastern Cape Province: South African Journal of Geology, v. 91, no. 3, p. 399-403.

King, L.C., 1953, Canons of landscape evolution: GSA Bulletin, v. 64, p. 721-752, doi: 10.1130/0016-7606(1953)64[721:COLE]2.0.CO;2.

Matmon, A., Bierman, P., and Enzel, Y., 2002, Pattern and tempo of great escarpment erosion: Geology, v. 30, no. 12, p. 1135-1138, doi: 10.1130/ 0091-7613(2002)030<1135:PATOGE $>2.0$. CO;2.

Nishiizumi, K., Kohl, C.P., Arnold, J.R., Klein, J., Fink, D., and Middleton, R., 1991, Cosmic ray produced ${ }^{10} \mathrm{Be}$ and ${ }^{26} \mathrm{Al}$ in Antarctic rocks; exposure and erosion history: Earth and Planetary Science Letters, v. 104, no. 2-4, p. 440-454, doi: 10.1016/0012-821X(91)90221-3.

Partridge, T.C., and Maud, R.R., 1987, Geomorphic evolution of Southern Africa since the Mesozoic: South African Journal of Geology, v. 90, no. 2, p. 179-208.

Pazzaglia, F.J., and Gardner, T.W., 1994, Late Cenozoic flexural deformation of the middle U.S. Atlantic passive margin: Journal of Geophysical Research,

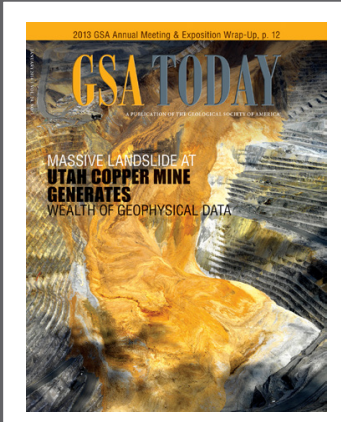

GSA Today is Open Access Online Go to www.geosociety.org/ pubs/ and click on the GSA Today cover.

Follow the link on the GSA Today homepage to sign up for e-Alerts and be the first to know when a new issue comes online.

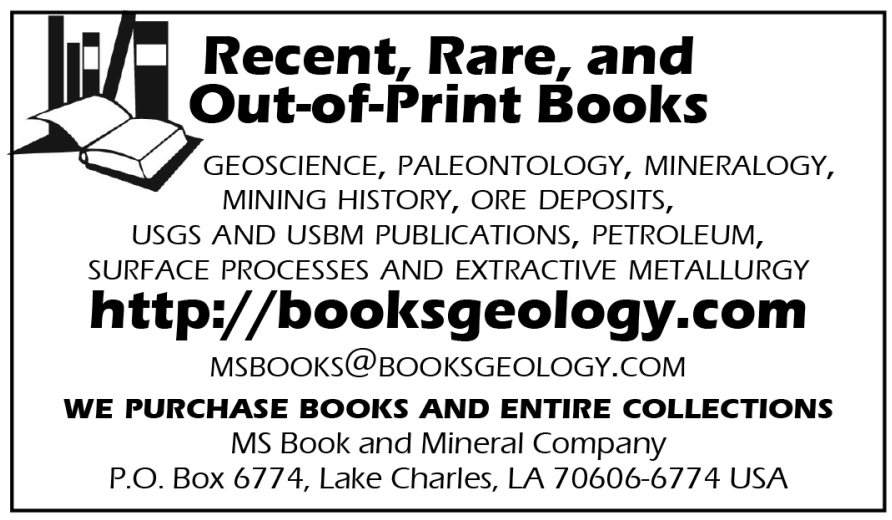

B, Solid Earth and Planets, v. 99, no. 6, p. 12,143-12,157, doi: 10.1029/ 93JB03130.

Portenga, E., and Bierman, P.R., 2011, Understanding Earth's eroding surface with ${ }^{10}$ Be: GSA Today, v. 21, no. 8, p. 4-10, doi: 10.1130/G111A.1.

Riebe, C.S., Kirchner, J.W., Granger, D.E., and Finkel, R.C., 2000, Erosional equilibrium and disequilibrium in the Sierra Nevada, inferred from cosmogenic ${ }^{26} \mathrm{Al}$ and ${ }^{10} \mathrm{Be}$ in alluvial sediment: Geology, v. 28, no. 9, p. 803-806, doi: 10.1130/0091-7613(2000)28<803:EEADIT>2.0.CO;2.

Scharf, T.E., Codilean, A.T., de Wit, M., Jansen, J.D., and Kubik, P.W., 2013, Strong rocks sustain ancient postorogenic topography in southern Africa: Geology, v. 41, no. 3, p. 331-334, doi: 10.1130/G33806.1.

Shanahan, T.M., and Zreda, M., 2000, Chronology of Quaternary glaciations in East Africa: Earth and Planetary Science Letters, v. 177, p. 23-42, doi: 10 $.1016 / \mathrm{S} 0012-821 \mathrm{X}(00) 00029-7$.

Summerfield, M.A., 1983, Geochemistry of weathering profile silcretes, southern Cape Province, South Africa: Geological Society of London Special Publication 11, p. 167-178, doi: 10.1144/GSL.SP.1983.011.01.17.

Tinker, J., de Wit, M., and Brown, R., 2008, Mesozoic exhumation of the southern Cape, South Africa, quantified using apatite fission track thermochronology: Tectonophysics, v. 455, p. 77-93, doi: 10.1016/ j.tecto.2007.10.009.

Van der Wateren, F.M., and Dunai, T.J., 2001, Late Neogene passive margin denudation history; cosmogenic isotope measurements from the central Namib Desert: Global and Planetary Change, v. 30, no. 3-4, p. 271-307, doi: 10.1016/S0921-8181(01)00104-7.

Vanacker, V., von Blanckenburg, F., Hewawasam, T., and Kubik, P.W., 2007, Constraining landscape development of the Sri Lankan escarpment with cosmogenic nuclides in river sediment: Earth and Planetary Science Letters, v. 253, no. 3-4, p. 402-414, doi: 10.1016/j.epsl.2006.11.003.

Manuscript received 18 Dec. 2013; accepted 13 Mar. 2014. 이

Outstanding Books from

\section{Cambridge University Press}

Large Igneous Provinces

RICHARD E. ERNST

\$130: Hb: 978-0-521-87177-8: $630 \mathrm{pp}$.

Geochemical Rate Models An Introduction to

Geochemical Kinetics

J. Donald Rimstidi

\$75: Hb: 978-1-107-02997-2: $239 \mathrm{pp}$

Extreme Natural Hazards, Disaster Risks and Societal Implications

Alik Ismail-ZADEH ET AL. \$140: Hb: 978-1-107-03386-3: $413 \mathrm{pp}$.

Foraminifera and their Applications

Robert WynN Jones \$75: Hb: 978-1-107-03640-6: $401 \mathrm{pp}$.

\begin{tabular}{|l|}
\hline \multicolumn{1}{|c|}{ Featured Textbooks } \\
Essentials of Igneous and \\
Metamorphic Petrology \\
B. RONALD FrosT AND \\
CAROL D. FROST \\
\$65:Pb: 978-1-107-69629-7: 310 pp. \\
Geophysics for the Mineral \\
Exploration Geoscientist \\
MICHAEL DENTITH, AND \\
STEPHEN T. MUDGE \\
$\$ 75:$ Hb: $9780521809511: 454$ pp. \\
Ore Deposit Geology \\
JOHN RIDLEY \\
$\$ 85:$ Hb: $978-1-107-02222-5: 409$ pp.
\end{tabular}

Attending GSA 2014? Visit the Cambridge University Press booth \#909 and receive a $20 \%$ discount off all books, enter

our raffle to win a book, and speak with editor, Dr. Emma Kiddle.

国閏 CAMBRIDGE www.cambridge.org/earth v@CambUP_earthsci 